Full length article

\title{
Geographical variation in relative risks associated with heat: Update of Spain's Heat Wave Prevention Plan
}

\author{
J. Díaz ${ }^{\text {a,* }}$, R. Carmona ${ }^{\text {a }}$, I.J. Mirón ${ }^{\text {b }}$, C. Ortiz a ${ }^{\text {a I. León }}{ }^{\text {c }}$ C. Linares ${ }^{\text {a }}$ \\ a National School of Public Health, Carlos III Institute of Health, Madrid, Spain \\ ${ }^{\mathrm{b}}$ Torrijos Public Health District, Castile-La Mancha Regional Health E'Social Affairs Authority (Consejería de Sanidad y Asuntos Sociales de Castilla-La Mancha), Torrijos (Toledo), Spain \\ c National Center of Epidemiology, Carlos III Institute of Health, Madrid, Spain
}

\section{A R T I C L E I N F O}

\section{Article history:}

Received 11 June 2015

Received in revised form 17 September 2015

Accepted 21 September 2015

Available online 2 October 2015

\section{Keywords:}

Heat waves

Mortality

Prevention plans

Geographical variation

Relative risks

\begin{abstract}
A B S T R A C T
A decade after the implementation of prevention plans designed to minimise the impact of high temperatures on health, some countries have decided to update these plans in order to improve the weakness detected in these ten years of operation.

In the case of Spain, this update has fundamentally consisted of changing the so-called "threshold" or "trigger" temperatures used to activate the plan, by switching from temperature values based on climatological criteria to others obtained by epidemiological studies conducted on a provincial scale.

This study reports the results of these "trigger" temperatures for each of Spain's 52 provincial capitals, as well as the impact of heat on mortality by reference to the relative risks (RRs) and attributable risks (ARs) calculated for natural as well as circulatory and respiratory causes.

The results obtained for threshold temperatures and RRs show a more uniform behaviour pattern than those obtained using temperature values based on climatological criteria; plus a clear decrease in RRs of heat-associated mortality due to the three causes considered, at both a provincial and regional level as well as for Spain as a whole.

The updating of prevention plans is regarded as crucial for optimising the operation of these plans in terms of reducing the effect of high temperatures on population health.
\end{abstract}

(c) 2015 Elsevier Ltd. All rights reserved.

\section{Introduction}

The effects that extreme temperatures have on mortality are evident, and there are a numerous publications which attest to this (Basu and Samet, 2002). Consequently, prevention or action plans have been implemented in many parts of the world to deal with extremely high temperatures. Nevertheless, in addition to the many uncertainties associated with determining the health impact of extreme temperatures (Konkel, 2014), when it comes to activating the action plans intended to counter the effects of such temperatures, different problems arise, linked, in great measure, to the lack of a common definition of what is known as a "heat wave" in public health (Montero et al., 2013).

The most of the studies considered as examples for illustration studies conducted using maximum daily temperature as the environmental variable to define heat waves, and daily mortality as the health variable to measure their impact (Wu et al., 2014; Zhang et al., 2014; Benmarhnia et al., 2014). Our goal is to define precisely at which specific temperature a heat wave can be deemed to exist, i.e., the point known as the "threshold" or "trigger" temperature. Some use

\footnotetext{
* Corresponding author at: National School of Public Health, Carlos III Institute of Health, Avda., Monforte de Lemos, 5, 28029 Madrid, Spain.

E-mail address: j.diaz@isciii.es (J. Díaz).
}

strictly climatological criteria for defining a heat wave, i.e., a heat wave exists when the maximum daily temperature exceeds the 95th percentile of the series of maximum daily temperatures for the summer months (Montero et al., 2010); and, others hold the view that a multitude of parameters, such as socio-economic, demographic factors and the different acclimatisation to warmer temperatures (Barret, 2015), affect the magnitude of mortality risk in response to a rise in temperatures. Specific epidemiological studies focusing on the mortalitytemperature relationship would have to be undertaken to determine the dose-response curve and whether indeed a temperature exists at which heat-related mortality starts to rise sharply (Montero et al., 2012). Establishing a threshold or trigger temperature for activating a heat health warning system (HHWS) is useful (Kovats and Kristie, 2006), and such a threshold can also be used for quantifying impacts of heat waves on mortality (Kent et al., 2014).

The Spanish Heat Wave Prevention Plan was first activated in 2004, and was based on threshold temperatures selected by reference to climatological criteria, which largely used the 95th percentile of the climatological temperature series for the summer months in the period 1971-2000 to determine the trigger temperature (MSSSI, 2015). Studies undertaken recently have highlighted the fact that, in certain cases, activation of the plan was not accompanied by the desired fall in mortality (Culqui et al., 2014; Linares et al., 2015b) and, moreover, 
that increases in heat-related mortality would have been observed even if the Plan had been activated (Montero et al., 2010). If the relative risks (RRs) associated with the threshold temperatures so obtained are calculated, these display a rather inconsistent behaviour pattern (Tobías et al., 2012), i.e., a few kilometres away from provinces with very high RRs, there are others with very low RRs.

These inconsistencies have led Spain's Ministry of Health, Social Services \& Equality (Ministerio de Sanidad, Servicios Sociales e Igualdad/ MSSSI) to reconsider the suitability of the plan which has been in place until now, and based on the criteria outlined above, to update the respective threshold temperatures established for the country's provincial capitals, with this serving as a basis for the 2015 National Plan for Preventive Actions against the Health Effects of Excess Temperatures (MSSSI, 2015).

The designated aim of this study was to pinpoint the maximum daily temperature above which a significant increase in heat-related mortality was observed for each of Spain's provincial capitals; and, to calculate the relative risks for an increment of each degree above the temperature threshold detected and associated attributable risks and ascertain how these were distributed geographically. This analysis extended to increases in daily heat-related mortality due not only to natural, but also to circulatory and respiratory causes.

\section{Methods}

\subsection{Setting}

Spain is the second largest country in Western Europe $\left(504,030 \mathrm{~km}^{2}\right)$, with a total population of $46,507,760$ (INE, 2014). Mainland Spain is bordered to the south and east by the Mediterranean Sea, to the north by France and the Bay of Biscay, and to the north-west and west by the Atlantic Ocean and Portugal. Spanish territory also includes the Balearic Islands in the Mediterranean, the Canary Islands in the Atlantic Ocean off the African coast, and two autonomous enclaves in North Africa, namely, the cities of Ceuta and Melilla. The country is divided into 17 Autonomous Regions (Comunidades Autónomas), which are in turn subdivided into one to nine provinces, each with its own respective provincial capital. Due to Spain's geographical situation and conditions, the climate is extremely diverse and can be roughly classified into the following five main zones: a Mediterranean climate extending along the southern and eastern coasts up to the Pyrenees; a semi-arid Mediterranean climate in the south-east; a continental Mediterranean climate in the inland areas of mainland Spain; an oceanic climate in the north-west and along the coastal strip bordering the Bay of Biscay; and a sub-tropical climate in the Canary Islands (Prieto et al., 2004).

\subsection{Data}

As the health variable, we used data on daily mortality due to natural causes (International Classification of Diseases 10th Revision (ICD-10): A00-R99), circulatory causes (ICD-10: I00-I99) and respiratory causes (ICD-10: J00-J99), in each of Spain's 52 provincial capitals and in towns and cities of over 10,000 inhabitants, across the period 1 January 2000 to 31 December 2009. The daily mortality data were obtained from microfiches containing death data broken down by cause of death and supplied under a data loan agreement by the National Statistics Institute to the Carlos III Institute of Health (Ministry of Economic Affairs \& Competitiveness/Ministerio de Economía y Competitividad), for the purpose of undertaking a "Study of influenza-related mortality in Spain". This analysis is an ecological design so it was exempt of ethics panel.

The maximum daily temperature data for this period corresponded to the records kept by the respective meteorological observatories in the various provincial capitals, and were furnished by the State Meteorological Agency (Agencia Estatal de Meteorología/AEMET), except in the case of Palencia for which there were no records for the period. The meteorological observatories were located in places established by the State Meteorological Agency (www.aemet.es).

There are different international approaches in literature to determine the threshold temperatures (Basu and Samet, 2002; Tong et al., 2010; Gasparrini et al., 2015). In this analysis we follow the methodology employed for determining the threshold temperatures used to define heat waves in the following papers: Montero et al., 2010; Mirón et al., 2012, 2015; Roldán et al., 2014; Linares et al., 2015a. The advantage of working with residuals rather than daily mortality is that, after modelling, residuals display neither trend nor periodicities (both of which are inherent in daily mortality), with the result that any associations found will therefore show a genuine causal mortality-temperature relationship from a statistical standpoint $(p<0.05)$ any associations between temperature and mortality, will not be confounded by longer term time trends and seasonal patterns. We first fitted a univariate autoregressive integrated moving average (ARIMA) model (Box et al., 1994) for daily mortality in each of the 52 provincial capitals, which allowed us to obtain the residuals of the mortality series. From the ARIMA models we obtained the fit and the confidence intervals corresponding to this fit (upper and lower). The residuals of mortality are the difference between the raw mortality and the fit. Then we proceeded to plot the following on a scatter plot diagram: the mean value of the mortality series residuals on the same day (vertical axis); the maximum daily temperatures at $2{ }^{\circ} \mathrm{C}$ intervals (horizontal axis), and their corresponding 95\% confidence intervals (CIs) (upper and lower limits of the CI: UL and LL respectively); and the 95\% CIs of the mean of the residuals for the entire study period ( shown by parallel broken lines). When these mortality residuals are showed in a scatter plot with the maximum temperature data, the deviations detected correspond to real mortality anomalies. The temperature from which the mortality residuals increased significantly vis-à-vis the mean would thus be the threshold temperature.

The impact of temperature on mortality was quantified, using generalised linear model (GLM) methodology, with the Poisson regression link. This methodology allows for calculation of the relative risks (RRs) associated with increases in the environmental variable, in this case temperature. Based on the RR, we then calculated the attributable risk (AR) associated with this increase via the following equation (Coste and Spira, 1991):

$\mathrm{AR}=[(\mathrm{RR}-1) / \mathrm{RR}] \times 100$.

On fitting the model, we controlled the following: firstly, for seasonalities of an annual, six-monthly and quarterly nature, using the sine and cosine functions with these same periodicities; and secondly, for trend and the possible autoregressive nature of the series.

To consider the effect of a heat wave through maximum daily temperatures (Tmax), we respectively created the variables Tcal, defined on the basis of the previously calculated mortality threshold temperatures (Tthreshold) as follows:

$$
\begin{array}{ll}
\text { Tcal }=0 & \text { if Tmax }<\text { Tthreshold } \\
\text { Tcal }=\text { Tmax-Tthreshold } & \text { if Tmax } \geq \text { Tthreshold } .
\end{array}
$$

From the point of view of mortality's impacts, we have considered heat-wave any day that surpasses the threshold considered in each city analysed (Díaz et al., 2002a,b).

Given that the effect of a heat wave on mortality may not be immediate, the following lagged variables were calculated: Tcal (lag 1), which takes into account the effect of the temperature on day "d" on mortality, one day later, "d + 1"; Tcal (lag 2), which takes into account the effect of the temperature on day " $\mathrm{d}$ " on mortality, two days later, " $\mathrm{d}+2$ "; and so on successively. The number of lags were selected on the basis of the literature, which establishes that the effect of heat is a short-term effect (Tcal: lags 1-4) (Alberdi et al., 1998). The trend was controlled through 
a variable in the data base that counts along the period. This variable starts the first day of the series being 1 on January 1 st of year 2000 and continues to the end of the series being 2963 on December 31st of 2009.

Significant variables (Tcal and its corresponding lags and the control variables) were determined using the step-step procedure, beginning with the model that included all the explanatory variables, and gradually eliminating those which individually displayed least statistical significance, with the process being reiterated until all the variables included were significant at $p<0.05$. Modelling was performed for the summer months (June to September). These RRs were calculated for both natural-cause and circulatory- and respiratory-cause mortality.

The increases in the RRs and ARs obtained refer to increases for each ${ }^{\circ} \mathrm{C}$ that the maximum daily temperature exceeded the threshold temperature.

The RRs for each province obtained by Poisson regression were combined using a random effect meta-analysis, which incorporates an estimate of between-study variation (heterogeneity) in the weighting
(Sterne, 2009) to obtain a measurement of $\mathrm{RR}(95 \% \mathrm{CI})$ at both a regional and national level.

All analyses were performed using the IBM SPSS Statistics v22 and STATA v11.2 statistical software programmes, with the ArcGIS v10.2.2 software programme being used for geographical representation.

\section{Results}

Table 1 shows the descriptive statistics of the dependent and independent variables used in this study.

By way of example, Fig. 1 shows, first a scatter plot diagram for raw natural-cause mortality, second, the residuals of the same mortality series after pre-whitened with the ARIMA model and by last, shows the mortality threshold temperature obtained for the city of Bilbao. As can be seen, from a maximum daily temperature of $30{ }^{\circ} \mathrm{C}$ upwards, the daily mortality residuals registered an anomalous, statistical significance value. This value coincided with the 88th percentile of the maximum temperature series for the summer months of this period.

Table 1

Descriptive statistics of mortality due to natural, respiratory and circulatory causes and maximum temperature $\left({ }^{\circ} \mathrm{C}\right)$ by city in Spain $2000-2009$ period.

\begin{tabular}{|c|c|c|c|c|c|c|c|c|c|c|c|c|c|c|c|c|}
\hline \multirow[t]{2}{*}{ City } & \multicolumn{4}{|c|}{ Natural mortality } & \multicolumn{4}{|c|}{ Respiratory mortality } & \multicolumn{4}{|c|}{ Circulatory mortality } & \multicolumn{4}{|c|}{ Maximum temperature } \\
\hline & Mean & SD & Min & Max & Mean & SD & Min & Max & Mean & SD & Min & Max & Mean & SD & Min & Max \\
\hline A Coruña & 28 & 6 & 12 & 51 & 3 & 2 & 0 & 11 & 10 & 3 & 2 & 23 & 22.5 & 2.7 & 15.1 & 34.5 \\
\hline Albacete & 8 & 3 & 1 & 18 & 1 & 1 & 0 & 5 & 3 & 2 & 0 & 10 & 31.2 & 4.3 & 12.4 & 40.6 \\
\hline Alicante & 32 & 6 & 13 & 59 & 3 & 2 & 0 & 10 & 12 & 4 & 2 & 26 & 29.7 & 2.5 & 20.2 & 38.2 \\
\hline Almería & 10 & 3 & 1 & 22 & 1 & 1 & 0 & 6 & 3 & 2 & 0 & 11 & 29.2 & 3.3 & 20.6 & 40.6 \\
\hline Ávila & 5 & 2 & 0 & 14 & 1 & 1 & 0 & 5 & 2 & 1 & 0 & 8 & 26.6 & 4.5 & 12.4 & 37.4 \\
\hline Badajoz & 15 & 4 & 3 & 34 & 2 & 1 & 0 & 7 & 5 & 2 & 0 & 16 & 33.2 & 4.2 & 19.3 & 44.8 \\
\hline Barcelona & 105 & 16 & 62 & 203 & 9 & 4 & 2 & 27 & 32 & 7 & 15 & 63 & 27.3 & 2.9 & 16.4 & 37.3 \\
\hline Bilbao & 25 & 5 & 11 & 45 & 2 & 1 & 0 & 9 & 8 & 3 & 1 & 17 & 24.8 & 4.2 & 14.8 & 41.9 \\
\hline Burgos & 9 & 3 & 0 & 24 & 1 & 1 & 0 & 6 & 3 & 2 & 0 & 10 & 26.7 & 5.1 & 12.2 & 38.8 \\
\hline Cáceres & 9 & 3 & 1 & 24 & 1 & 1 & 0 & 6 & 3 & 2 & 0 & 12 & 31.8 & 4.5 & 17.4 & 42.6 \\
\hline Cádiz & 21 & 5 & 7 & 44 & 2 & 2 & 0 & 9 & 7 & 3 & 0 & 17 & 26.8 & 3.2 & 19.5 & 38.0 \\
\hline Castellón & 11 & 3 & 3 & 26 & 1 & 1 & 0 & 5 & 4 & 2 & 0 & 13 & 29.4 & 2.6 & 19.0 & 40.6 \\
\hline Ciudad Real & 12 & 4 & 1 & 26 & 1 & 1 & 0 & 6 & 4 & 2 & 0 & 12 & 32.3 & 4.6 & 14.2 & 41.7 \\
\hline Córdoba & 17 & 5 & 2 & 49 & 2 & 2 & 0 & 11 & 6 & 2 & 0 & 15 & 35.0 & 4.2 & 20.4 & 46.2 \\
\hline Cuenca & 5 & 2 & 0 & 13 & 1 & 1 & 0 & 5 & 2 & 1 & 0 & 7 & 29.4 & 4.4 & 13.6 & 38.4 \\
\hline Girona & 14 & 4 & 3 & 29 & 1 & 1 & 0 & 6 & 5 & 2 & 0 & 13 & 29.0 & 3.9 & 14.4 & 41.2 \\
\hline Granada & 18 & 4 & 6 & 34 & 2 & 1 & 0 & 8 & 6 & 3 & 0 & 16 & 32.4 & 4.2 & 17.3 & 42.1 \\
\hline Guadalajara & 4 & 2 & 0 & 12 & 1 & 1 & 0 & 4 & 1 & 1 & 0 & 8 & 31.3 & 4.6 & 14.7 & 40.7 \\
\hline Huelva & 10 & 3 & 1 & 25 & 1 & 1 & 0 & 7 & 4 & 2 & 0 & 12 & 31.2 & 3.9 & 20.6 & 43.8 \\
\hline Huesca & 6 & 2 & 0 & 15 & 1 & 1 & 0 & 5 & 2 & 1 & 0 & 7 & 29.7 & 4.3 & 15.4 & 41.3 \\
\hline Jaén & 13 & 4 & 2 & 28 & 2 & 1 & 0 & 6 & 5 & 2 & 0 & 15 & 31.1 & 4.4 & 17.8 & 41.2 \\
\hline Las Palmas & 15 & 4 & 6 & 35 & 1 & 1 & 0 & 7 & 5 & 2 & 0 & 15 & 26.6 & 2.0 & 22.3 & 38.9 \\
\hline León & 13 & 4 & 3 & 27 & 1 & 1 & 0 & 8 & 4 & 2 & 0 & 12 & 25.5 & 4.5 & 12.0 & 36.2 \\
\hline Logroño & 6 & 3 & 0 & 16 & 1 & 1 & 0 & 5 & 2 & 2 & 0 & 10 & 28.8 & 4.9 & 14.6 & 40.6 \\
\hline Lugo & 11 & 3 & 1 & 23 & 1 & 1 & 0 & 6 & 4 & 2 & 0 & 11 & 24.3 & 4.2 & 13.2 & 39.1 \\
\hline Lleida & 9 & 3 & 1 & 22 & 1 & 1 & 0 & 5 & 3 & 2 & 0 & 9 & 31.2 & 3.9 & 15.4 & 40.8 \\
\hline Madrid & 98 & 13 & 58 & 164 & 13 & 4 & 1 & 36 & 28 & 6 & 9 & 52 & 29.9 & 4.3 & 13.7 & 38.6 \\
\hline Málaga & 28 & 6 & 9 & 47 & 3 & 2 & 0 & 10 & 10 & 3 & 0 & 23 & 30.0 & 3.5 & 22.0 & 42.0 \\
\hline Murcia & 23 & 5 & 9 & 43 & 2 & 2 & 0 & 9 & 8 & 3 & 1 & 19 & 27.9 & 2.9 & 20.4 & 40.8 \\
\hline Ourense & 10 & 3 & 1 & 23 & 1 & 1 & 0 & 6 & 4 & 2 & 0 & 13 & 29.5 & 4.6 & 16.6 & 42.0 \\
\hline Oviedo & 29 & 6 & 15 & 58 & 3 & 2 & 0 & 10 & 10 & 3 & 1 & 25 & 22.7 & 3.5 & 11.5 & 35.6 \\
\hline Pamplona & 12 & 4 & 3 & 29 & 1 & 1 & 0 & 8 & 4 & 2 & 0 & 12 & 27.2 & 5.4 & 12.8 & 39.8 \\
\hline P. Mallorca & 19 & 5 & 6 & 37 & 2 & 1 & 0 & 9 & 7 & 3 & 1 & 17 & 30.0 & 3.2 & 20.2 & 41.4 \\
\hline Pontevedra & 19 & 5 & 7 & 36 & 2 & 1 & 0 & 8 & 6 & 3 & 0 & 16 & 24.8 & 4.0 & 14.0 & 39.5 \\
\hline Salamanca & 9 & 3 & 1 & 23 & 1 & 1 & 0 & 5 & 3 & 2 & 0 & 10 & 28.5 & 4.5 & 13.2 & 39.0 \\
\hline Santander & 13 & 4 & 3 & 26 & 2 & 1 & 0 & 7 & 4 & 2 & 0 & 14 & 23.3 & 2.9 & 16.0 & 37.3 \\
\hline S.C.Tenerife & 15 & 4 & 5 & 37 & 1 & 1 & 0 & 6 & 5 & 2 & 0 & 15 & 28.3 & 2.2 & 23.1 & 39.7 \\
\hline Segovia & 4 & 2 & 0 & 12 & 0 & 1 & 0 & 4 & 1 & 1 & 0 & 6 & 27.7 & 4.7 & 10.0 & 38.3 \\
\hline Sevilla & 34 & 7 & 14 & 81 & 3 & 2 & 0 & 11 & 14 & 4 & 3 & 39 & 34.4 & 4.0 & 20.6 & 45.2 \\
\hline Soria & 3 & 2 & 0 & 9 & 0 & 0 & 0 & 3 & 1 & 1 & 0 & 5 & 26.9 & 4.9 & 11.8 & 36.8 \\
\hline S.Sebastián & 14 & 4 & 4 & 33 & 1 & 1 & 0 & 8 & 4 & 2 & 0 & 12 & 21.7 & 3.9 & 13.4 & 38.6 \\
\hline Tarragona & 15 & 4 & 4 & 31 & 1 & 1 & 0 & 7 & 5 & 2 & 0 & 14 & 31.5 & 3.3 & 17.6 & 40.0 \\
\hline Teruel & 4 & 2 & 0 & 13 & 0 & 1 & 0 & 3 & 1 & 1 & 0 & 7 & 29.2 & 4.6 & 13.6 & 38.8 \\
\hline Toledo & 13 & 4 & 1 & 29 & 1 & 1 & 0 & 7 & 4 & 2 & 0 & 12 & 32.6 & 4.4 & 16.9 & 42.0 \\
\hline Valencia & 51 & 8 & 30 & 79 & 5 & 2 & 0 & 14 & 17 & 4 & 4 & 31 & 29.2 & 2.8 & 18.3 & 40.3 \\
\hline Valladolid & 11 & 4 & 2 & 23 & 1 & 1 & 0 & 6 & 4 & 2 & 0 & 12 & 28.6 & 4.7 & 12.2 & 39.5 \\
\hline Vitoria & 5 & 2 & 0 & 13 & 0 & 1 & 0 & 4 & 2 & 1 & 0 & 7 & 25.0 & 5.1 & 11.8 & 38.0 \\
\hline Zamora & 6 & 2 & 0 & 16 & 1 & 1 & 0 & 4 & 2 & 1 & 0 & 7 & 28.7 & 4.5 & 13.0 & 39.2 \\
\hline Zaragoza & 22 & 5 & 8 & 42 & 2 & 1 & 0 & 9 & 7 & 3 & 0 & 17 & 30.8 & 4.6 & 16.5 & 43.1 \\
\hline
\end{tabular}


If the threshold temperature is calculated in this way for each of the 52 provincial capitals (except Palencia for which there were no meteorological data), Fig. 2 is obtained. These threshold temperatures ranged from $26{ }^{\circ} \mathrm{C}$ in Corunna (A Coruña) to $40{ }^{\circ} \mathrm{C}$ in Cordoba, Seville and Malaga. The percentiles to which the temperatures in Fig. 2 correspond in relation to the maximum daily temperature series for this period are shown in Fig. 3: these ranged from the 82nd percentile in the province of Madrid to the 99th percentile in the province of Malaga. Of the provincial capitals analysed, 19 registered percentiles equal to or higher than the 95th percentile which was the basis of the MSSSI's earlier prevention plan (MSSSI, 2015), 9 coincided with the 95th percentile, and the remainder were lower.

If the RRs associated with an increase of $1{ }^{\circ} \mathrm{C}$ are calculated for each provincial capital, the results shown in Fig. 4 are obtained. In addition, this figure depicts the RRs for each Autonomous Region and for Spain as a whole.

This figure shows that the RRs for provincial capitals ranged from $1.27(1.21-1.32)$ in the case of Caceres to $1.03(1.00-1.06)$ in the case of Murcia, with these differences proving statistically significant.

At a regional level, the values were very similar, both within and among the respective Autonomous Regions, with Navarre displaying the highest RR, 1.19 (1.13-1.25), and Murcia displaying the lowest RR, 1.03 (1.00-1.06); once again, these differences proved statistically significant, though in the case of the provinces of Teruel and Soria the effect of heat on mortality failed to display statistically significance.

For Spain overall, the RR was 1.11 (1.10-1.12).

As a general rule, threshold temperatures corresponding to low percentiles were found to be associated with low RRs, whereas threshold temperatures corresponding to high percentiles tended to be accompanied by higher RRs.

Fig. 5 shows the ARs for each provincial capital, which logically coincided with their RR distribution, inasmuch as ARs are calculated on the basis of RRs.

Lastly, Figs. 6 and 7 depict the forest plot resulting from the metaanalysis, showing the RRs of circulatory- and respiratory-cause mortality for each provincial capital, each Autonomous Region and the country as a whole. As will be seen, generally speaking, the effect was greater for respiratory-cause than for circulatory-cause mortality; and indeed, this difference even proved statistically significant for Spain overall. Likewise, the number of capitals in which there was a heat-related effect for respiratory but not for circulatory causes, was also higher.

\section{Discussion}

The results of the different mortality threshold temperatures observed in Fig. 2 points to the phenomenon of heat habituation by populations in accordance with the range of temperatures to which they are exposed (Kovats et al., 2006; Keatinge et al., 2000; Curriero et al., 2002), and show that what for some provinces is a comfort or minimum mortality temperature, in others might be considered a threshold temperature for heat-related mortality (Díaz et al., 2006). In relation to the percentiles shown in Fig. 3, there are multiple factors as demographic, traditionally the age group of over 65 is the most susceptible to the heat effects (Diaz et al., 2015) and the population pyramid is different from one area to another. Another factors as socio-economics, such as the access to air conditioning and the existence of infrastructure adapted to extreme temperatures, and even public health factors, as inequalities in access to health services and the quality of these is different, for last cultural differences as acclimation to heat, which cause these to vary from one place to another (Montero et al., 2012; Naughton et al., 2002; Nakai et al., 1999; Vandentorren et al., 2006).

It is of interest to analyse whether, in addition to the spatial variation described above, there might also be temporal variation. In this regard, if the threshold temperatures reported here are compared to others previously calculated in other studies undertaken with similar methodology and, needless to say, using older data series than those used by us, the following changes will be seen to have taken place (Table 2).

This confirms the evolution over time of the above heat-related mortality threshold temperatures (Linares et al., 2014a). As can be seen, these temperatures fell in three provincial capitals, rose in four, and remained the same in two. This different behaviour pattern from one place to another could be due to the existence of two mutually opposing effects. On the one hand, population ageing in Spain necessarily involves an increase in the over-65 age group, the main group in which heatwave mortality rises most sharply (Díaz et al., 2002a; Montero et al., 2012), and this in turn means that such ageing would lead to a lowering of heat-related mortality threshold temperatures. Counteracting this effect of a fall in thresholds - something that is directly related to the effectiveness of prevention plans (Meusel et al., 2004; Abrahamson et al., 2008) - are medical and technological advances that will play an important role from the point of view of mitigating the impact of heat waves. Then again, strategies in the construction of buildings, such as the creation of green areas, and the use of heat-absorbent construction

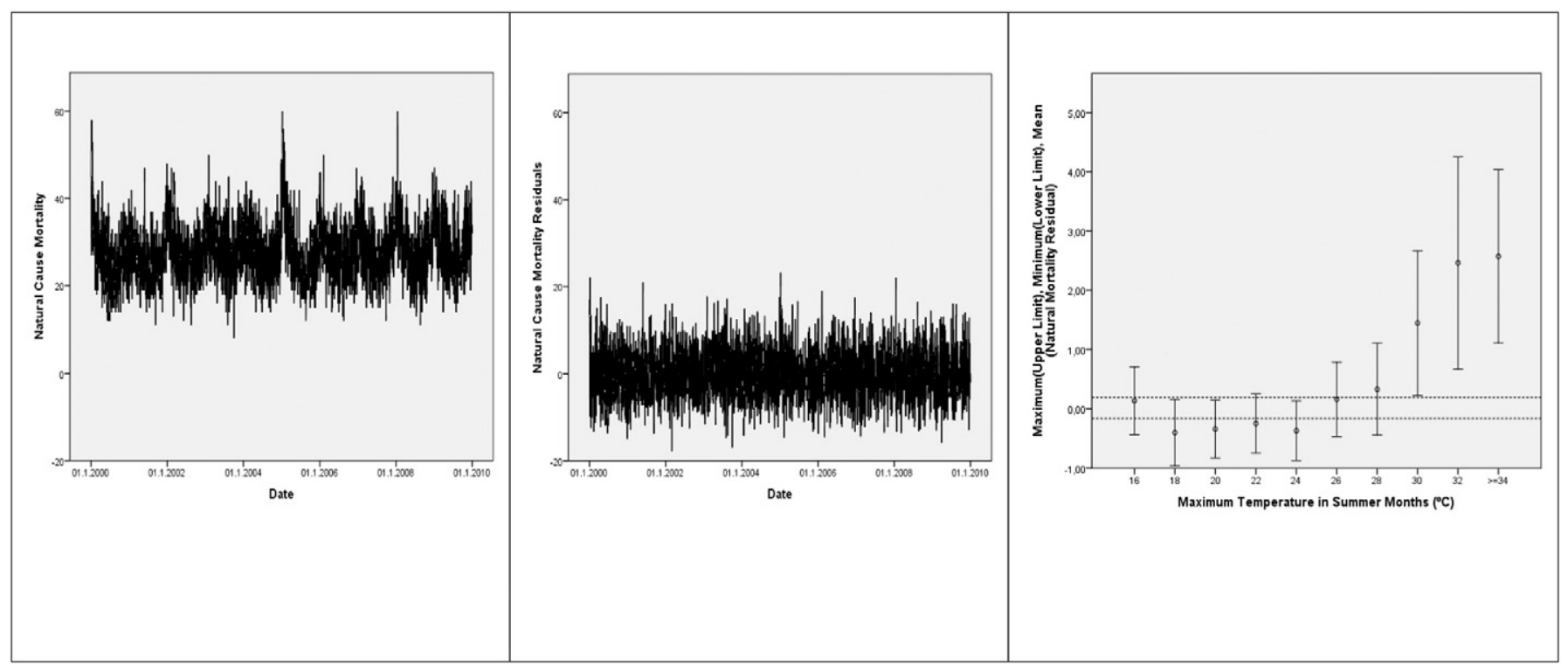

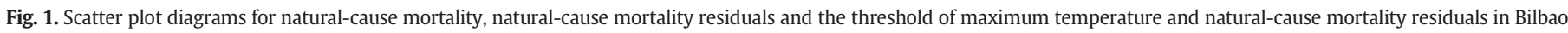
(Spain). 


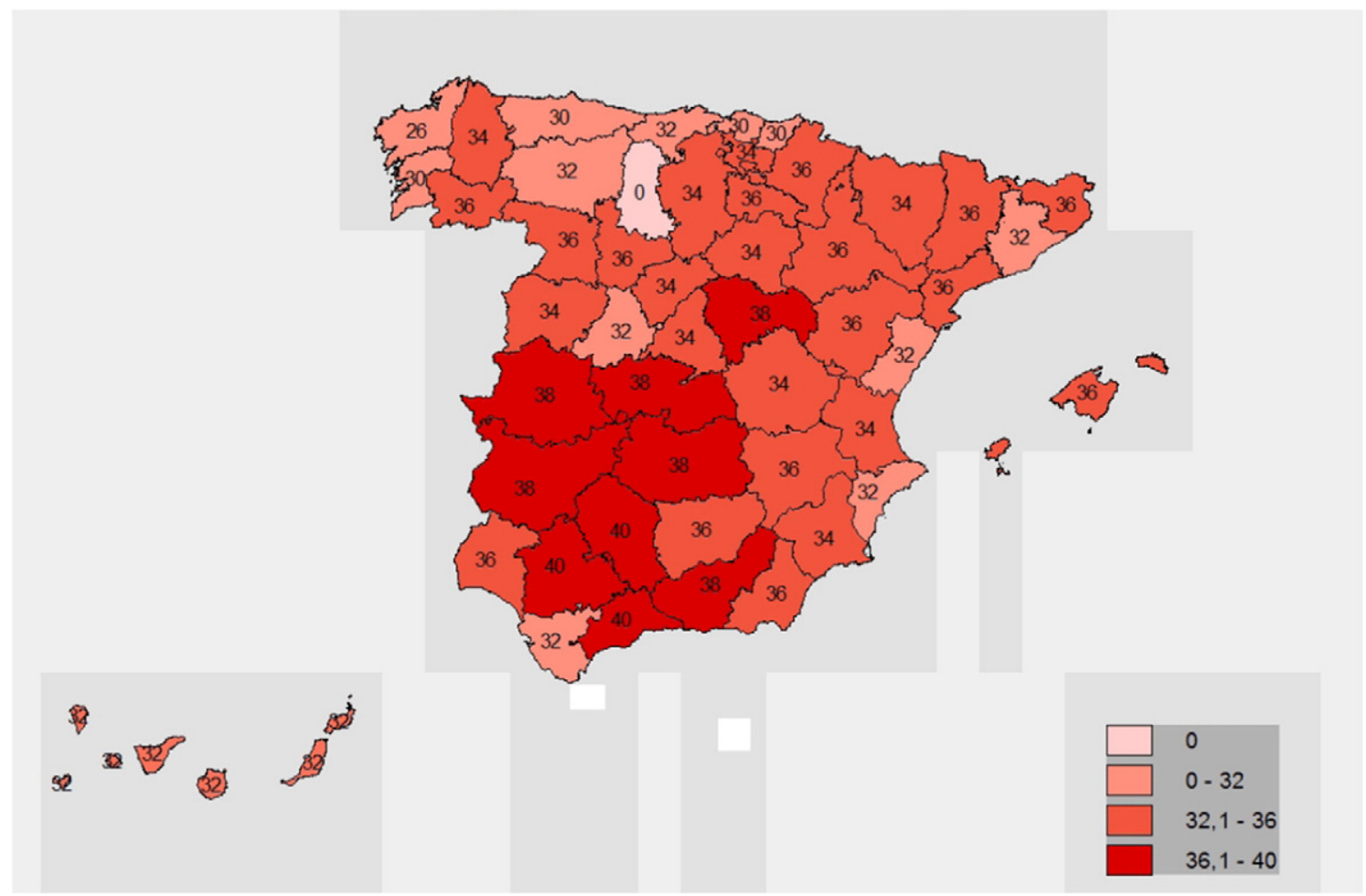

Fig. 2. Maximum temperature threshold's $\left({ }^{\circ} \mathrm{C}\right)$ for daily mortality attributable to heat due to natural causes corresponding to $2000-2009$ period in Spain.

materials and structures that allow for heat transfer and ideal air circulation might be capable of bringing about a reduction of $1{ }^{\circ} \mathrm{C}$ to $2{ }^{\circ} \mathrm{C}$ in the temperature of any given environment (Georgescu et al., 2014). Lastly, the resilience of a population in terms of adapting to heat would mean that the effects of thermal extremes on the population would tend to diminish (Gosling et al., 2009). Depending on the area in question, the predominance of any one of these factors could account for the decrease or increase in threshold temperatures. The fact that "Threshold temperatures corresponding to low percentiles were found to be associated with low RRs, whereas threshold temperatures corresponding to high percentiles tended to be accompanied by higher RRs" is not contrary with the biophysically or infrastructural

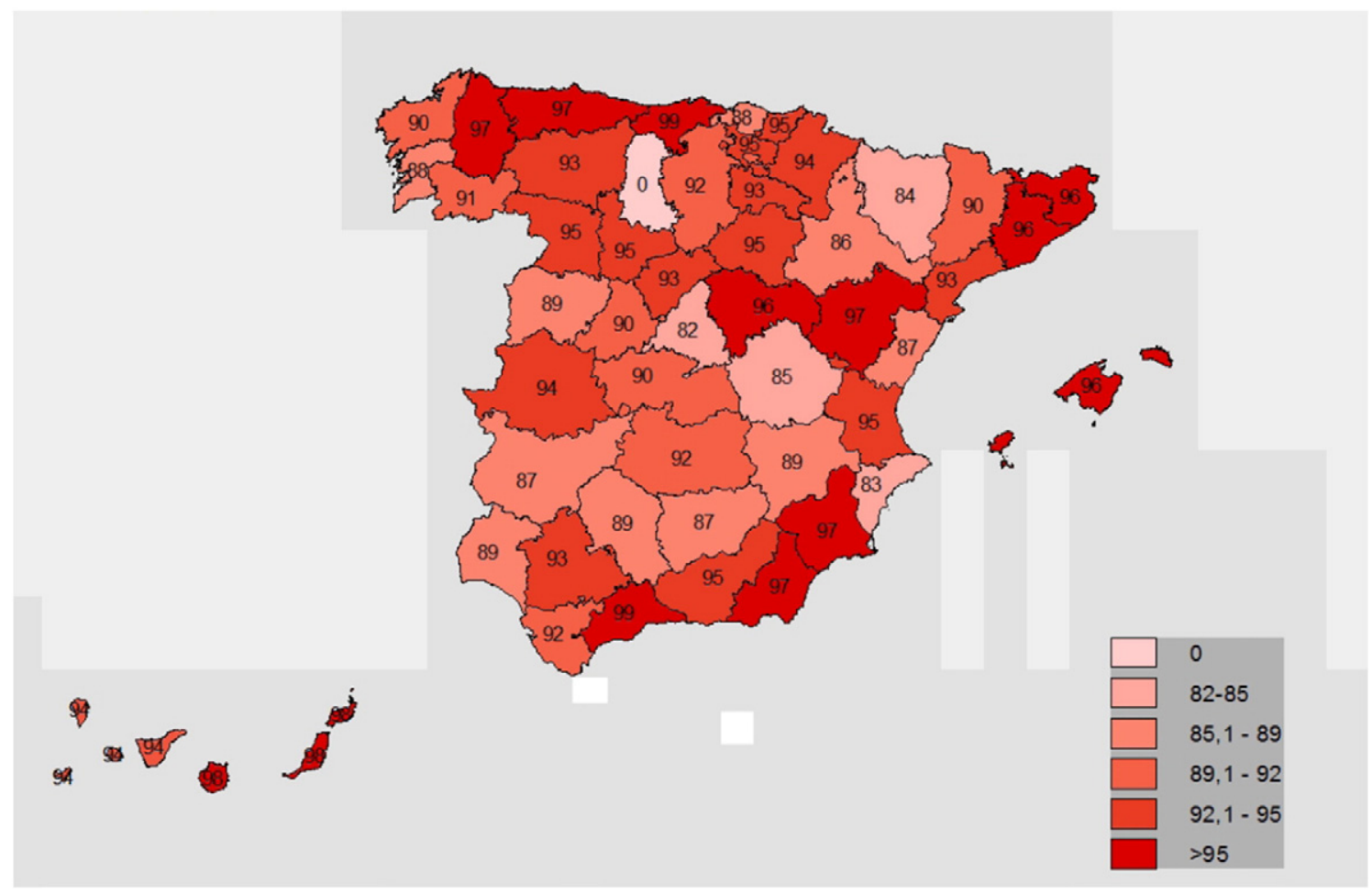

Fig. 3. Percentiles of the series of maximum daily temperatures associated with heat-mortality due to natural causes in the period $2000-2009$ in Spain. 
considerations about warmer cities, where the trigger threshold for mortality should be higher. However, as our findings showed, high percentiles imply that those events occurs rarely and from a "statically point of view", the mortality due to heat should be divided among these little extreme events, that leads to higher AR.
When it comes to analysing the RRs of natural-cause mortality shown in Fig. 4 or their corresponding ARs in Fig. 5, it is interesting to compare these values to those previously obtained for Spain using mortality data corresponding to the period 1995-2004 (Tobías et al., 2012). Tobías et al.'s study calculated by how much the risk of dying had

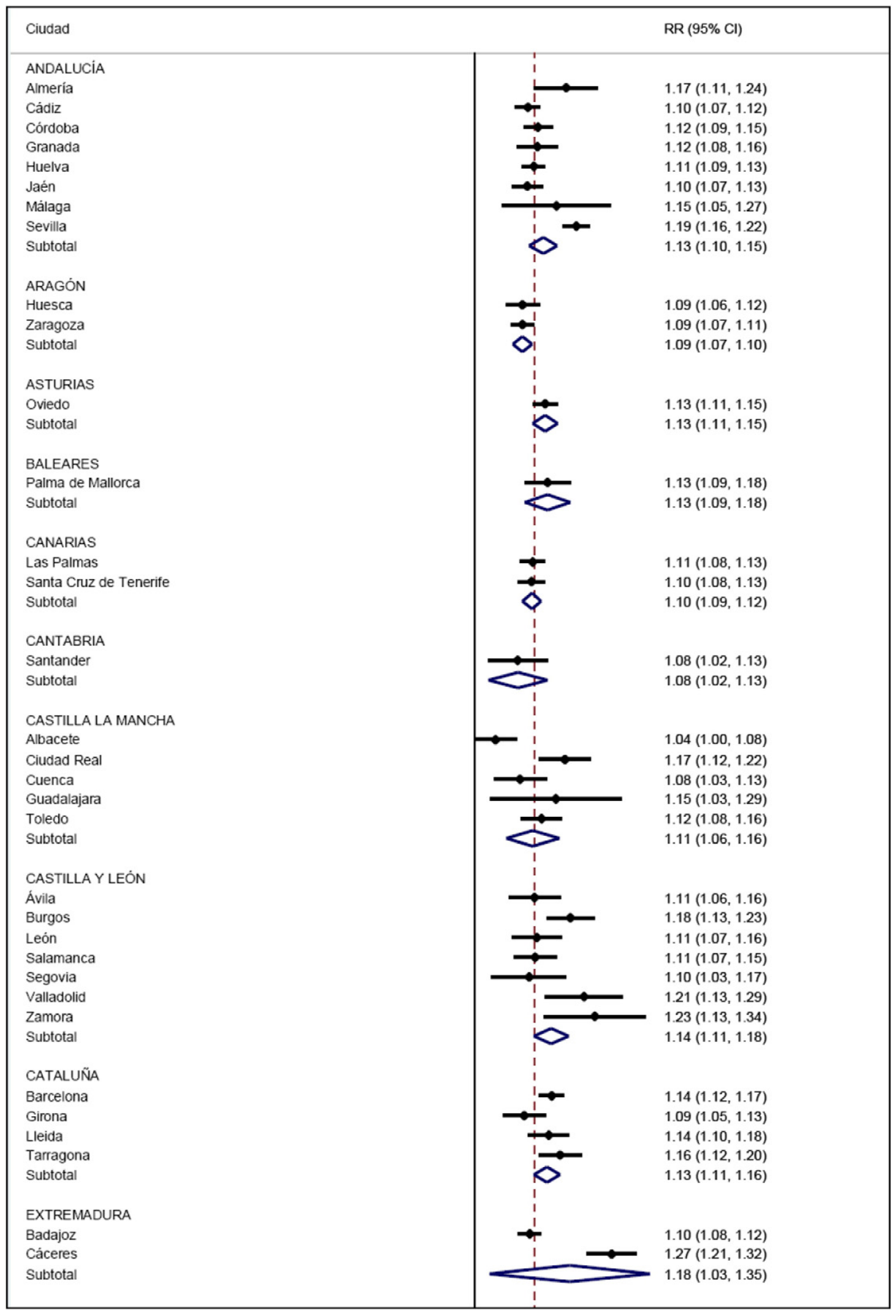

Fig. 4. Relative risks (RRs) calculated for increases of $1{ }^{\circ} \mathrm{C}$ over the threshold temperature associated to heat due to natural-causes mortality in Spain. 


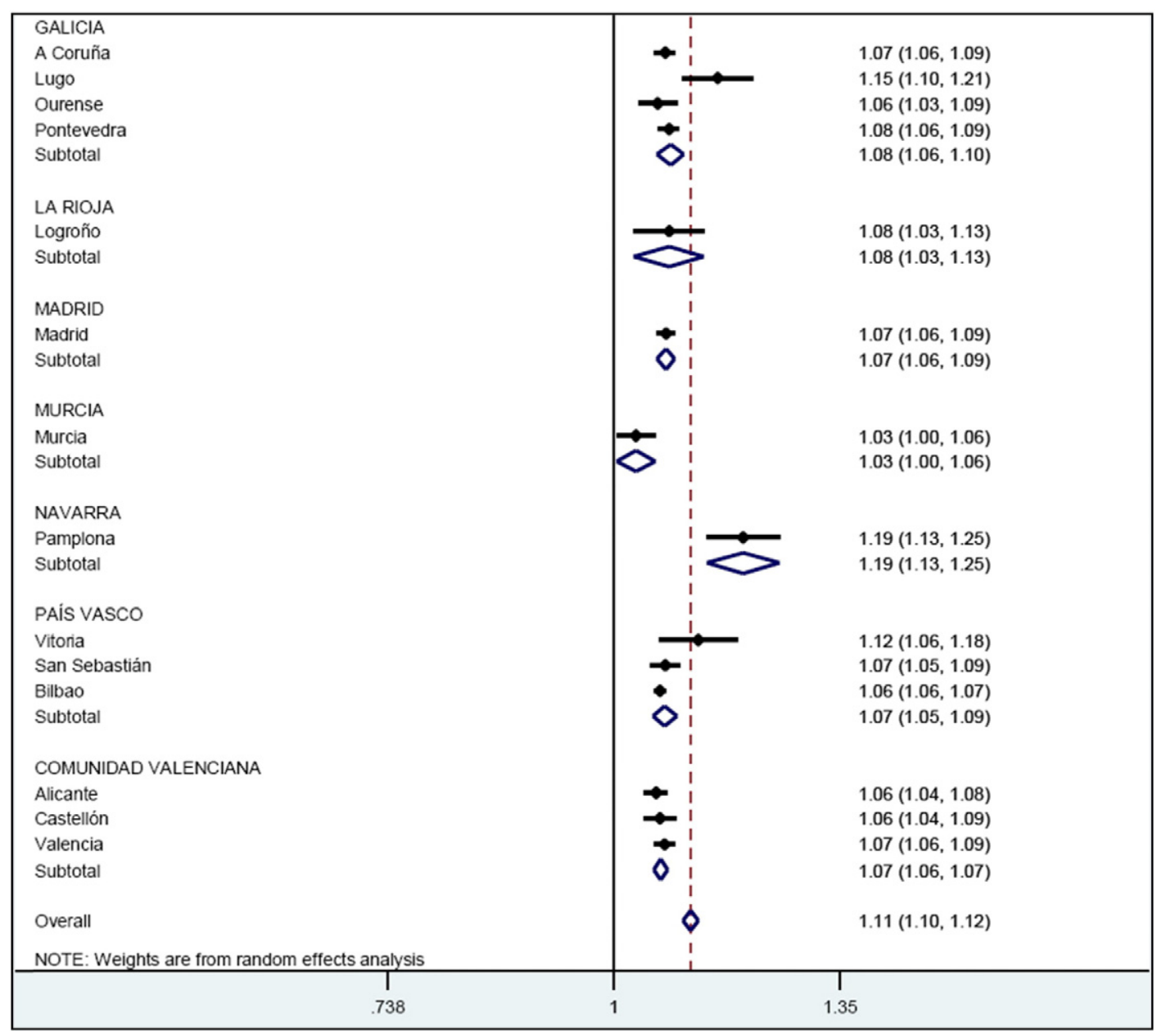

Fig. 4 (continued).

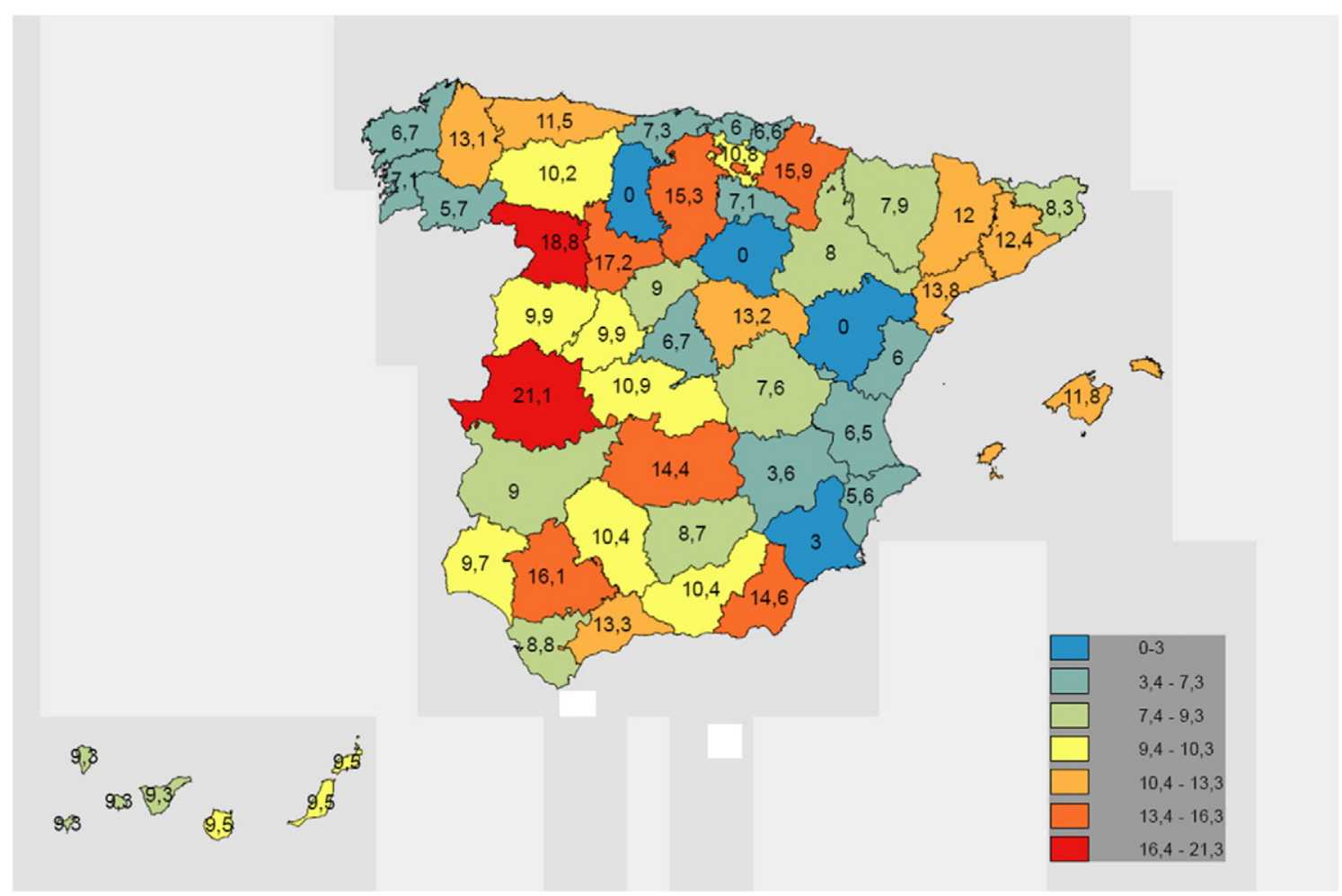

Fig. 5. Attributable risk (\%) associated to heat-mortality when exceeded the temperature thresholds in Spain in the period $2000-2009$. 
Ciudad

ANDALUCÍA

Cádiz

Córdoba

Granada
Huelva

Jaén

Málaga

Sevilla

Subtotal

ARAGÓN

Huesca

Zaragoza

Subtotal

ASTURIAS

Oviedo

Subtotal

BALEARES

Palma de Mallorca

Subtotal

\section{CANARIAS}

Santa Cruz de Tenerife

Santa Cr
Subtotal

CANTABRIA

Santander

Subtotal

CASTILLA LA MANCHA

Ciudad Real

Guadalajara

Subtotal

CASTILLA Y LEÓN

Burgos

León

Salamanca

Valladolid

CATALUÑA
Barcelona

Lleida

Subtotal

EXTREMADURA

Badajoz

Cáceres

Subtotal

GALICIA

A Coruña

Lugo

Ourense

Pontevedra

Subtotal

LA RIOJA

Logroño

Subtotal

MADRID

Madrid

Subtotal

NAVARRA

Pamplona

Subtotal

PAís VASCO

Vitoria

San Sebastián

Bilbao

Subtotal

COMUNIDAD VALENCIANA

Alicante

Castellón

Valencia

Subtotal

Overall

NOTE: Weights are from random effects analysis
$\mathrm{RR}(95 \% \mathrm{Cl})$

$1.11(1.07,1.15)$

$1.16(1.11,1.21)$

$1.23(1.16,1.30)$

$1.08(1.05,1.12)$

$1.09(1.04,1.14)$

$1.21(1.04,1.40)$

$1.30(1.25,1.34)$

$1.16(1.10,1.23)$

$1.05(1.00,1.10)$

$1.06(1.03,1.09)$

$1.06(1.03,1.08)$

$1.14(1.10,1.18)$

$1.14(1.10,1.18)$

$1.17(1.10,1.24)$

$1.17(1.10,1.24)$

$1.13(1.08,1.17)$

$1.06(1.03,1.10)$

$1.09(1.03,1.16)$

$1.12(1.03,1.22)$

$1.12(1.03,1.22)$

$1.12(1.05,1.20)$

$1.28(1.07,1.53)$

$1.17(1.04,1.31)$

$1.12(1.05,1.19)$

$1.10(1.04,1.18)$

$1.07(1.01,1.13)$

$1.16(1.06,1.28)$

$1.10(1.07,1.14)$

$1.16(1.13,1.19)$

$1.17(1.10,1.24)$

$1.16(1.14,1.19)$

$1.07(1.04,1.11)$

$1.24(1.15,1.33)$

$1.15(1.00,1.32)$

$1.03(1.01,1.05)$

$1.11(1.03,1.19$

$1.08(1.04,1.12)$

$1.07(1.05,1.10$
$1.06(1.03,1.10)$

$1.10(1.02,1.19)$

$1.10(1.02,1.19)$

$1.08(1.06,1.09)$

$1.08(1.06,1.09)$

$1.22(1.14,1.31)$

$1.22(1.14,1.31)$

$1.10(1.00,1.22)$

$1.09(1.05,1.13)$

$1.04(1.03,1.06)$

$1.06(1.03,1.10)$

$1.06(1.04,1.09)$

$1.06(1.03,1.10)$

$1.06(1.04,1.09)$

$1.06(1.05,1.08)$

$1.11(1.09,1.13)$ 


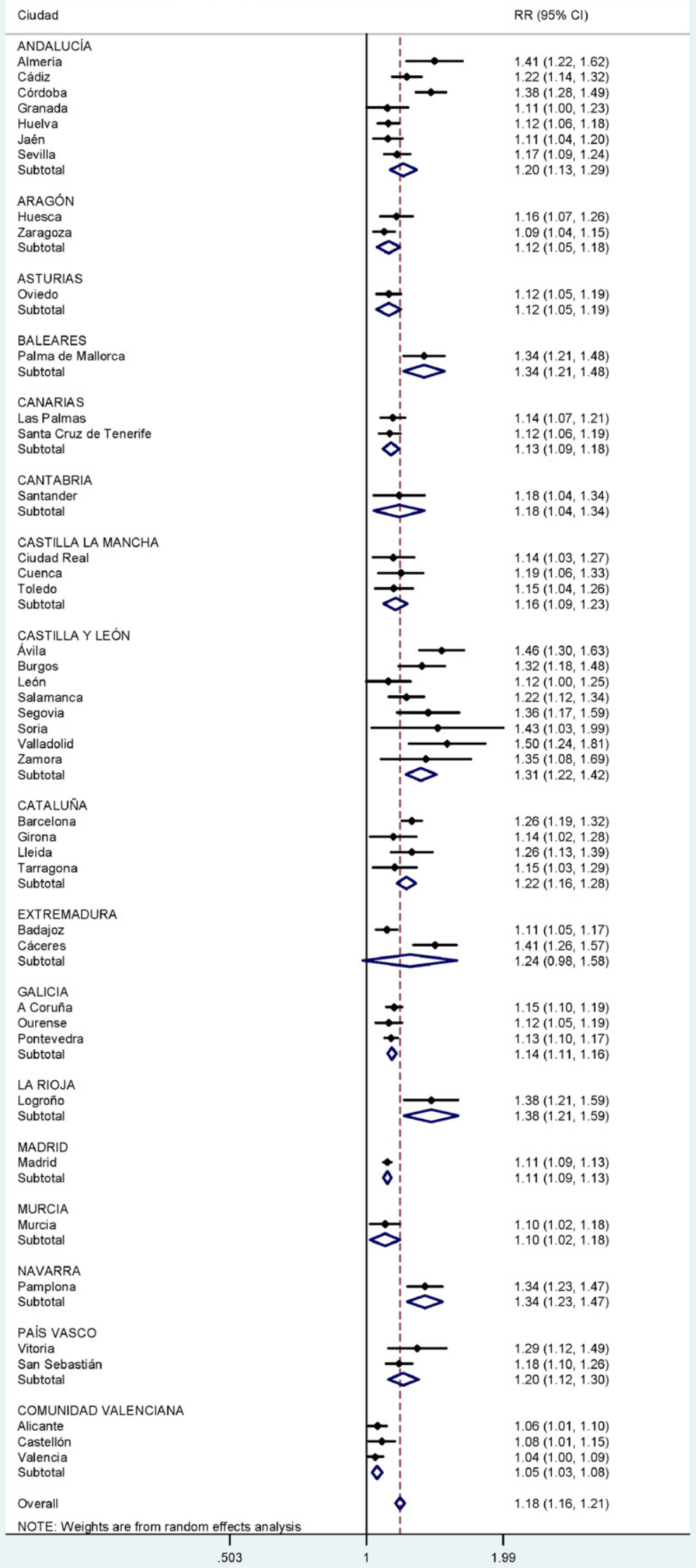

Fig. 7. Relative risks (RRs) calculated for increases of $1{ }^{\circ} \mathrm{C}$ over the threshold temperature associated to heat due to respiratory-causes mortality in Spain. 
Table 2

Evolution of maximum temperature threshold's in some Spanish cities.

\begin{tabular}{lllll}
\hline \multirow{2}{*}{ City } & \multicolumn{2}{l}{ Previous thresholds } & \multirow{2}{*}{ Actual thresholds } \\
\cline { 2 - 4 } & Value & Period & References & \\
\hline Madrid & $36.5^{\circ} \mathrm{C}$ & $1986-1997$ & Díaz et al. (2002a) & $34{ }^{\circ} \mathrm{C}$ \\
$\begin{array}{l}\text { Barcelona } \\
\text { Sevilla }\end{array}$ & $30.5{ }^{\circ} \mathrm{C}$ & $1999-2003$ & Tobías et al. (2010) & $32{ }^{\circ} \mathrm{C}$ \\
Zaragoza & $41.2^{\circ} \mathrm{C}$ & $1986-1997$ & Díaz et al. (2002b) & $40{ }^{\circ} \mathrm{C}$ \\
& $38{ }^{\circ} \mathrm{C}$ & $1987-2006$ & Roldán et al. (2015) & $36{ }^{\circ} \mathrm{C}$ \\
Toledo & $38{ }^{\circ} \mathrm{C}$ & $1975-2003$ & Montero et al. (2012) & $38{ }^{\circ} \mathrm{C}$ \\
$\begin{array}{l}\text { Guadalajara } \\
\text { Albacete }\end{array}$ & $35{ }^{\circ} \mathrm{C}$ & $1975-2003$ & Montero et al. (2012) & $38{ }^{\circ} \mathrm{C}$ \\
Cuenca & $36{ }^{\circ} \mathrm{C}$ & $1975-2003$ & Montero et al. (2012) & $36{ }^{\circ} \mathrm{C}$ \\
\hline
\end{tabular}

increased on days on which the thresholds applicable up to now had been exceeded (MSSSI, 2015), based fundamentally on the 95th percentile of the climate series. If our current results are compared to those yielded by Tobías et al.'s study, it will be seen that in this latter study there were many towns and cities in which the RR was less than unity (i.e., there was no effect of heat on mortality), and yet there were others in which the effect of heat was very pronounced. In other words, there was a lack of uniformity in the pattern of risk associated with heatrelated mortality, not only at the level of contiguous Autonomous Regions but also at that of neighbouring provincial capitals. This irregular behaviour pattern is less evident in the results shown in Figs. 4 and 5, in which the RRs were calculated for each provincial capital from the mortality residuals scatter plot diagrams. As has been pointed out, threshold temperatures calculated in this way, take into account a far broader range of the underlying factors that influence the different mortality patterns and vary from one region to another, such as the population pyramid, socio-economic and cultural levels, etc. When using strictly climatological criteria, these differences are not reflected, and translate as a lack of homogeneity in neighbouring regions, as stated above.

Finally, it should be noted that the heat-related RR for Spain as a whole according to Tobías et al.'s study was 1.24 (1.19-1.30), a figure significantly higher than that of $1.11(1.10-1.12)$ obtained for Spain overall with the thresholds calculated ad hoc for each provincial capital. This lower effect of heat on mortality could be due to two factors: on the one hand, there is the lowering of the percentiles to which the mortality threshold temperatures correspond, which would lead to the relative risks being accordingly lower; and on the other, there is the possible decline in the effects of heat over time. This latter aspect coincides with what has been detected in recent studies, in the sense that the effects of extreme temperatures, far from remaining constant, are changing over time (Sheridan et al., 2008; Davis et al., 2003a,b), with a trend towards the minimisation of such effects (Schifano et al., 2012; Gasparrini et al., 2015); and, whereas the impact of this has been most pronounced in the case of mortality due to cardiovascular causes (Ha and Kim, 2013), the effect has remained practically constant in the case of mortality due to respiratory causes (Mirón et al., 2015). This behaviour pattern would appear to be related to the improvement in health services, particularly among patients with cardiovascular diseases, and the above-described socio-economic improvements and improvements in housing infrastructures and living conditions. Even so, such improvements in health services and town planning could be affected by situations and economic cycles that might reverse the situation and increase the effects of thermal extremes on mortality (Díaz et al., 2015).

The distribution de RRs for circulatory and respiratory causes is logically similar to that displayed by mortality due to natural causes, since the latter are what most contribute to heat-related mortality (Díaz et al., 2002a).

Moreover, the finding that heat has less effect on circulatory-cause than on respiratory-cause mortality coincides both with the abovedescribed trend and with studies recently undertaken in the central part of Spain (Mirón et al., 2015). In this case, the decline in circulatory-cause mortality has been very marked, falling from an AR of $30.3 \%$ in the decade from 1986 to 1997 to $7.3 \%$ in the decade from 1997 to 2008. In the case of respiratory-cause mortality in contrast, the decline has been far less pronounced (16.3\% versus $13.7 \%$ ).

With respect to the limitations of this study and any possible resulting biases, the following should be mentioned: firstly, in the case of an ecological study such as ours, does not permit inferences to be made at the level of individuals, for fear of the ecological fallacy arising as a result of the use of pooled data. With reference to the quality and consistency of the data analysed, there might possibly have been poor classification of the cause of mortality. Other possible limitation is about the representativeness of the temperature recorded always in the capital of province, there are some previously papers that argue this point (Mirón et al., 2006; Roldán et al., 2011). With regard to the non-use of other environmental variables of interest, such as air pressure and relative humidity, these were not included in the analysis owing to their negligible relevance in the temperature-mortality relationship (Barnett et al., 2010; Montero et al., 2012). Insofar as particulate air pollution is concerned, the lack of quality data at a national level rendered it their use inadvisable, owing to the risk of introducing instability into the complete series, in the sense that air pollutants into the GLM models modify lightly the impact of heat waves on mortality (Linares et al., 2014b).

Furthermore, when it comes to methodological limitations, mention should essentially be made of two shortcomings inherent in a statistical method which works with a high number of variables at a 95\% confidence level. The use of low daily numbers of deaths in some cities, generally leads to higher confidence intervals and a lower accurate findings. This fact explain not age-adjust in our sample.

Another point is about the efficiency of the Spanish prevention plans until the year 2014. The results obtained in previous assessments showed, that these prevention plans do not result in a lower impact of mortality attributable to heat (Kalkstein and Davis, 1989; Montero et al., 2010; Culqui et al., 2014; Linares et al., 2015b). Nowadays, not only due to improvements in health services, but also, in general, to socio-economic improvements and the provision of infrastructures for better living conditions, the revised prevention plans or merely the acclimatisation of the population to heat (Konkel, 2014) could suppose a decrease in heat waves impacts (Mirón et al., 2015). The reduction in the impacts of the heat waves detected in no way implies that these are not going to be important in the future, since this reduction in impact will, very probably, be offset by increases in heat-wave frequency and intensity (IPCC, 2013).

In our opinion, these results amount to a change of paradigm when it comes to defining a heat wave. Such a definition cannot be static. Not only is it impossible to establish a single temperature that would serve for all latitudes, but one cannot even establish a percentile of a series of temperatures to which a population will be exposed, since the relationship between temperature and mortality varies over time. In contrast, it is the search for a threshold temperature through consistent epidemiological studies at which efforts to define a heat wave should be targeted: that is to say, in accordance with the area studied, efforts should be targeted at defining from precisely which temperature the effects of heat on the health variables considered are to be deemed unacceptable.

There can be no doubt that the threshold temperature set in this way will be the consequence of the social, economic and demographic characteristics of a given society. This will in turn ensure that implementation of prevention plans based on exceedance of the thresholds so determined will result in a reduction in the impact of high temperatures on the health of the population.

\section{Acknowledgements}

This study was supported by grants FIS ENPY 1001/13 \& SEPY 1037/ 14 from Spain's Health Research Fund. 


\section{References}

Abrahamson, V., Wolf, J., Lorenzoni, I., et al., 2008. Perceptions of heatwave risks to health: interview-based study of older people in London and Norwich, UK. J. Public Health 31, 119-126.

Alberdi, J.C., Díaz, J., Montero, J.C., Mirón, I.J., 1998. Daily mortality in Madrid community 1986-1992: relationship with meteorological variables. Eur. J. Epidemiol. 14, 571-578.

Barnett, A.G., Tong, S., Clements, A.C.A., 2010. What measure of temperature is the best predictor of mortality? Environ. Res. 110, 604-611.

Barret, J.R., 2015. Increased minimum mortality temperature in France. Environ. Health Perspect. 123, A184

Basu, R., Samet, J.M., 2002. Relation between elevated ambient temperature and mortality: a review of the epidemiologic evidence. Epidemiol. Rev. 24, 190-202.

Benmarhnia, T., Sottile, M.F., Plante, C., Brand, A., Casati, B., Fournier, M., Smargiassi, A., 2014. Variability in temperature-related mortality projections under climate change. Environ. Health Perspect. 11 (12), 1293-1298.

Box, G.E., Jenkins, G.M., Reinsel, C., 1994. Time Series Analysis. Forecasting and Control. Prentice Hall, Englewood.

Coste, J., Spira, A., 1991. Le proportion de cas attributable en Santé Publique: definition(s), estimation(s) et interpretation. Rev. Epidemiol. Sante Publique 51, 399-411.

Culqui, D.R., Diaz, J., Simón, F., Tobías, A., Linares, C., 2014. Evaluation of the plan for surveillance and controlling of the effects of heat waves in Madrid. Int. J. Biometeorol. 58, 1799-1802.

Curriero, F.C., Heiner, K.S., Samet, J.M., Zeger, S.L., Strug, L., Patz, J.A., 2002. Temperature and mortality in 11 cities of the Eastern United States. Am. J. Epidemiol. 155, 80-87.

Davis, R.E., Knappenberger, P.C., Michaels, P.J., Novicoff, W.M., 2003a. Changing heatrelated mortality in the United States. Environ. Health Perspect. 111, 1712-1718.

Davis, R.E., Knappenberger, P.C., Novicoff, W.M., Michaels, P.J., 2003b. Decadal changes in summer mortality in U.S. cities. Int. J. Biometeorol. 47, 166-175.

Diaz, J., Carmona, R., Mirón, I.J., Ortiz, C., Linares, C., 2015. Comparison of the effect of extreme temperatures on daily mortality in Madrid, Spain by age group: the need for a cold wave prevention plan. Environ. Res. (in press).

Díaz, J., Carmona, R., Mirón, I.J., Sánchez, R., Linares, C., 2015. Time trend in natural-cause, circulatory-cause and respiratory-cause mortality associated with cold waves in Spain, 1975-2008. Stoch. Environ. Res. Risk Assess. (in press).

Díaz, J., García, R., Velázquez, F., López, C., Hernández, E., Otero, A., 2002b. Effects of extremely hot days on people older than 65 in Seville (Spain) from 1986 to 1997. Int. J. Biometeorol. 46, 145-149.

Díaz, J., García-Herrera, R., Trigo, R.M., Linares, C., Valente, M.A., De Miguel, J.M., et al., 2006. The impact of the summer 2003 heat wave in Iberia: how should we measure it? Int. J. Biometeorol. 50, 159-166.

Díaz, J., Jordán, A., García, R., et al., 2002a. Heat waves in Madrid 1986-1997: effects on the health of the elderly. Int. Arch. Occup. Environ. Health 75, 163-170.

Gasparrini, A., Guo, Y., Hashizume, M., Kinney, P., Petkova, E.P., Lavigne, E., et al., 2015 Temporal variation in heat-mortality associations: a multicountry study. Environ. Health Perspect. http://dx.doi.org/10.1289/ehp.1409070.

Georgescu, M., Morefield, P.E., Bierwagen, B.G., Weaver, C.P., 2014. Urban adaptation can roll back warming of emerging megapolitan regions. Proc. Natl. Acad. Sci. 111 (8), 2909-2914.

Gosling, S.N., McGregor, G.R., Lowe, J.A., 2009. Climate change and heat-related mortality in six cities part 2: climate model evaluation and projected impacts from changes in the mean and variability of temperature with climate change. Int. J. Biometeorol. 53, 31-51.

Ha, J., Kim, H., 2013. Changes in the association between summer temperature and mortality in Seoul, South Korea. Int. J. Biometeorol. 57, 535-544.

INE, 2014. Cifras de Población a 1 de enero de 2014. INE (publicadas en junio de, www. ine.es).

IPCC, 2013. Climate change (2013). The physical science basis. Working Group I Contribution to the Fifth Assessment Report of the Intergovernmental Panel on Climate Change.

Kalkstein, L.S., Re, D., 1989. Weather and human mortality: an evaluation of demographic and inter-regional responses in the United States. Ann. Assoc. Am. Geogr. 79, 44-64.

Keatinge, W.R., Donaldson, G.C., Cordioli, E., Martinelli, M., Kunst, A.E., Mackenbach, J.P., et al., 2000. Heat-related mortality in warm and cold regions of Europe: an observational study. Br. Med. J. 321, 670-673.

Kent, S.A., McClure, L.A., Zaitchik, B.F., Smith, T.T., Gohlke, J.M., 2014. Heat waves and health outcomes in Alabama (USA): the importance of heat wave definition. Environ. Health Perspect. 122, 151-158.

Konkel, L., 2014. Learning to take the heat: declines in U.S. heat-related mortality. Environ. Health Perspect. http://dx.doi.org/10.1289/ehp.122-A220.

Kovats, R.S., Kristie, L.E., 2006. Heatwaves and public health in Europe. Eur. J. Pub. Health 16 (6), 592-599.

Kovats, R.S., Johnson, H., Griffith, C., 2006. Mortality in southern England during the 2003 heat wave by place of death. Health Stat. Q. 29, 6-8 (Spring).

Linares, C., Carmona, R., Díaz, J., 2014b. Análisis del impacto a corto plazo de los extremos térmicos y de otros factores ambientales sobre la mortalidad diaria en la ciudad de Madrid en el periodo 2001-2009. Reports I and II Prepared for the European Commission Under the BASE (Bottom-UP Climate Adaptation Strategies Towards a Sustainable Europe) Project, 7th Research Framework Programme Under GA No. 308,337.
Linares, C., Díaz, J., Tobías, A., Carmona, R., Mirón, I.J., 2015a. Impact of heat and cold waves on circulatory-cause and respiratory-cause mortality in Spain: 1975-2008. Stoch. Environ. Res. Risk Assess. http://dx.doi.org/10.1007/s00477-014-0976-2.

Linares, C., Montero, J.C., Mirón, I.J., Criado-Álvarez, J.J., Díaz, J., 2014a. The time trend temperature-mortality as a factor of uncertainty analysis of impacts of future heat waves. Environ. Health Perspect. http://dx.doi.org/10.1289/ehp.1306670.

Linares, C., Sánchez, R., Montero, J.C., Mirón, I.J., Criado-Álvarez, J.J., Díaz, J., 2015b. Is there a decrease in mortality due to heat waves in Spain? Findings from a multicity case study. J. Integr. Environ. Sci. 12, 153-163.

Meusel, D., Menne, B., Kirch, W., Bertollini, R., 2004. Public health responses to extreme weather and climate events. A brief summary of the WHO meeting on this topic in Bratislava 9-10 February 2004. J. Public Health 12, 371-381.

Mirón, I.J., Montero, J.C., Criado, J.J., Gutiérrez, G., Paredes, D., Mayoral, S., Linares, C., 2006. Tratamiento y estudio de series de temperatura para su aplicación en salud pública. El caso de Castilla - La Mancha. Rev. Esp. Salud Publica 80, 113-124.

Mirón, I.J., Montero, J.C., Criado-Álvarez, J.J., Linares, C., Díaz, J., 2012. Intense cold and mortality in Castile-La Mancha (Spain): study of mortality trigger thresholds from 1975 to 2003. Int. J. Biometeorol. 56, 145-152.

Mirón, I.J., Montero, J.C., Criado-Álvarez, J.J., Linares, C., Díaz, J., 2015. Time trends in causespecific mortality during heat waves in Castile-La Mancha: Spain, 1975-2008. Int. J. Biometeorol. 59, 1213-1222.

Montero, J.C., Mirón, I.J., Criado, J.J., Linares, C., Díaz, J., 2012. Influence of local factors in the relationship between mortality and heat waves: Castile-La Mancha (1975-2003). Sci. Total Environ. 414, 73-80

Montero, J.C., Mirón, I.J., Criado, J.J., Linares, C., Díaz, J., 2013. Difficulties of defining the term "heat wave" in public health. Int. J. Environ. Health Res. 5, 377-379.

Montero, J.C., Mirón, I.J., Criado-Álvarez, J.J., Linares, C., Díaz, J., 2010. Comparison between two methods of defining heat waves: a retrospective study in Castille-La Mancha (Spain). Sci. Total Environ. 408, 1544-1550.

MSSSI. Ministerio de Sanidad, Servicios Sociales e Igualdad, 2015. http://www.msssi.gob. es/ciudadanos/saludAmbLaboral/planAltasTemp/2015/docs/Plan_Nacional_de_ Exceso_de_Temperaturas_2015.pdf.

Nakai, S., Itoh, T., Marimoto, T., 1999. Deaths from heat-stroke in Japan: 1968-1994. Int. J. Biometeorol. 43, 124-127.

Naughton, M.P., Henderson, A., Mirabelli, M., Kaiser, R., Wilhelm, J.L., Kieszak, S.M., et al., 2002. Heat-related mortality during a 1999 heatwave in Chicago. Am. J. Prev. Med. 22, 221-227.

Prieto, L., García-Herrera, R., Díaz, J., Hernández Tesoa, T., 2004. Minimum extreme temperatures over peninsular Spain. Glob. Planet. Chang. 44, 59-71.

Roldán, E., Gómez, M., Pino, R., Díaz, J., 2014. The impact of extremely high temperatures on mortality and mortality cost. Int. J. Environ. Health Res. http://dx.doi.org/10.1080/ 09603123.2014 .938028$.

Roldán, E., Gómez, M., Pino, M.R., Esteban, M., Díaz, J., 2011. Determinación de zonas isoclimáticas y selección de estaciones meteorológicas representativas en Aragón como base para la estimación del impacto del cambio climático sobre la posible relación entre la mortalidad y temperatura. Rev. Esp. Salud Publica 85, 603-610.

Roldán, E., Gómez, M., Pino, M.R., Pórtoles, J., Linares, C., Diaz, J., 2015. The effect of climate-change-related heat waves on mortality in Spain: uncertainties in health on a local scale. Stoch. Environ. Res. Risk Assess. http://dx.doi.org/10.1007/s00477015-1068-7 (in press).

Schifano, P., Leone, M., De Sario, M., de Donato, F., Bargagli, A.M., Díppoliti, D., et al., 2012. Changes in the effects of heat on mortality among the elderly from 1998-2010: results from a multicenter time series study in Italy. Environ. Heal. 1, 58 .

Sheridan, S.C.. Kalkstein, A.J., Kalkstein, L.S., 2008. Trends in heat-related mortality in the United States, 1975-2004. Nat. Hazards http://dx.doi.org/10.1007/s11069-008-9327-2.

State Meteorological Agency (Agencia Estatal de Meteorología/AEMET) Agencia Estatal de Metereología (www.aemet.es).

Sterne, J.A.C. (Ed.), 2009. Meta-Analysis in Stata: An Updated Collection From the Stata Journal. Stata Press (ISBN-13: 978-1-59718-049-8).

Tobías, A., de Olalla, P.B., Linares, C., Bleda, M.J., Caylá, J.A., Díaz, J., 2010. Short-term effect of extreme hot summer temperatures on total daily mortality in Barcelona, Spain. Int. J. Biometeorol. 54, 115-117.

Tobías, A., Zuza, I., Armstrong, B., Gasparrini, A., Linares, C., Díaz, J., 2012. Mortality on extreme heat days using official thresholds in Spain: a multi-city time series analysis. BMC Public Health 12, 133.

Tong, S., Whang, X.Y., Burnett, A.G., 2010. Assessment of heat-related health impacts in Brisbane, Australia: comparison of different heatwave definitions. PLoS One 5 (8), e12155. http://dx.doi.org/10.1371/journal.pone.0012155.

Vandentorren, S., Bretin, P., Zeghnoun, A., Mandereau-Bruno, L., Croisier, A., Cochet, C., et al., 2006. August 2003 heat wave in France: risk factors for death of elderly people living at home. Eur. J. Pub. Health 16, 583-591.

Wu, J., Zhou, Y., Gao, Y., Fu, J.S., Johnson, B.A., Huang, C., et al., 2014. Estimation and uncertainty analysis of impacts of future heat waves on mortality in the Eastern United States. Environ. Health Perspect. 122, 10-16.

Zhang, K., Chen, Y.H., Schwartz, J.D., Rood, R.B., O'Neill, S., 2014. Using forecast and observed weather data to assess performance of forecast products in identifying heat waves and estimating heat wave effects on mortality. Environ. Health Perspect. 11 (9), 912-918. 